\title{
Die liefde wat die son beweeg en die ander sterre: Digterlike transendering - tot die vermenigvuldigde lewe ontroer
}

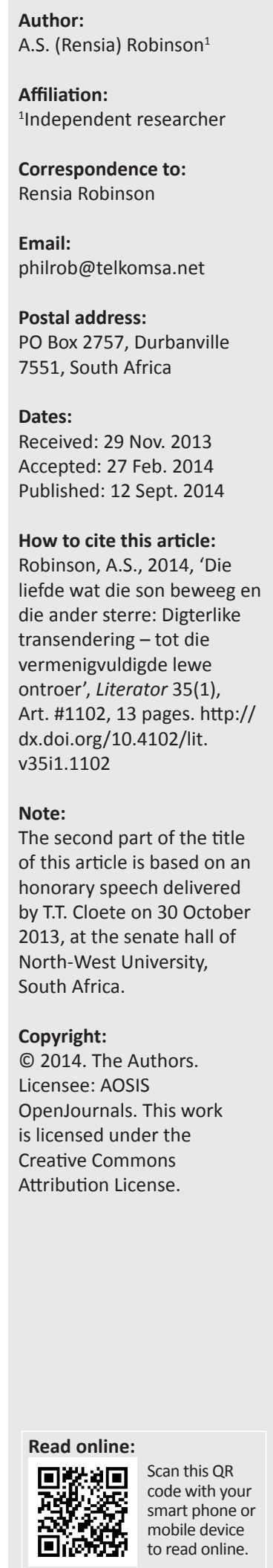

T.T. Cloete se oeuvre word onder andere gekenmerk deur fyn waarneming van 'n mistieke vervlegtheid in die skepping. Dit word op vele maniere ontgin en geïnterpreteer. Die poëtiese potensiaal van die vrou, in uiteenlopende gestaltes, is een van die sentrale temas waardeur die digter hieraan vorm gee. In die kunstige, bibliofiele uitgawe Uit die wit lig van my land gesny val die lig op die vrou se kreatiewe rol in die groter skepping wat haar onder andere identifiseer as haarveer vir digterlike insig en vormgewing. Vrou (alternatief Anna Perenna, universele moeder), is nie slegs draer van die lewenskiem wat tot gees transendeer nie, maar sy funksioneer as ligbron ('sonvrou') wat selfs kosmiese insig verwesenlik. Dit raak meervoudige vorms en patrone waarin die mens ingeweef is in die universele hologram van lewe. Vir die digter is hierdie patroonvorming vergelykbaar met die maak van Persiese tapyte waarvan die patrone vasgelê is in die geheue van voorouers, en oorgedra word na opeenvolgende geslagte. In dié verkenning word digterlike transendering ontgin as ' $n$ proses waarin die kleurvolheid van lewe en dood in en deur individuele sowel as universele vroulikheid geïnspireer word.

The love that moves the sun and the other stars - Poetic transcendence, stirred to live the multifaceted life: The oeuvre of T.T. Cloete may be characterised, among other possibilities, by a sensitive perception of a mystic interconnectedness in creation. This interconnectedness is developed and interpreted in many ways. The poetic potential of the female (Woman), in different forms, is one of the central themes being activated. In a recently published de luxe publication, Uit die wit lig van my land gesny, the poet focuses on the creative role of woman in the grand act of creation, identifying her role as a kind of hair-spring of poetic inspiration and design. Woman, alternatively Anna Perenna, the Universal Mother, is not only bearer of an embryo being transformed unto spirit, but she also acts as a source of light ('sun woman'), actualising cosmic insight. It is part of the interwoven patterns characterising humankind's place in a hologram of life. The poet compares these poetic patterns to the weaving of Persian rugs. The ancient forms inscribed in the memories of ancestors are communicated to the next generation. Poetic transcendence is developed as a process through which a wealth of colours of life and death is inspired by individual as well as universal femininity.

\section{Inleiding}

'n Verkenning van enige aspek van T.T. Cloete se oeuvre kom te staan voor die spreekwoordelike spinnerak waar die aanraking van 'n enkele draadjie die hele netwerk laat vibreer. Dit tipeer ook Cloete se verstaan van 'die heelal waarin alles met alles vir hom saamhang'. Hy sê verder: 'Gedigte wys hierdie samehang uit, stuksgewys, brok vir brok, nooit heeltemal volledig nie'. In die bundel Driepas gebruik hy bo aan die gedig 'Snuffel' die motto: 'the universe fatigues with its infinitude' (Cloete 1989:176). In sy oeuvre word sy uitgangspunt dat 'die gedig mimeties is van die skeppingsgedagte' op vele maniere sigbaar (Cloete 1984:15). Relevant vir die kunstige bibliofiele uitgawe Uit die wit lig van my land gesny is hiernaas sy uitspraak:

Ons moet nie vergeet nie, eenheid impliseer veelvoud, veelheid, detail. Die digterlike orgaan is saam met sy eenheidsbewussyn verfynd bewus van die detail in die skepping. Daar is oorweldigende detail, en jy sóú daarvan mal kon word as jy dit nie kon orden in 'n kunswerk nie, as jy dit nie kon vertaal tot ' $n$ orde nie ... die dromende denke (is) byvoorbeeld ' $n$ kwantitatiewe, gesegmenteerde denke, en 'n verhoudingsdenke. Dit is 'n koherente, kompositoriese instrument. (Cloete 1984:15; kyk ook Cloete 1970:167-196)

Laasgenoemde uitgangspunt kan moeilik treffender geïllustreer word as deur die totstandkoming van so 'n kompositoriese bundel soos die genoemde een 'vir Anna', na die beëindiging van haar fisieke aardse lewe. 


\section{'n Universaliserende uitgangspunt}

In 'n omvattende verkenning van sy eie digterlike motiverings in die sleutelwerk Die ander een is ek, wat ek wil tipeer as digterlike transparante, wys die digter, T.T. Cloete (2003) op die volgende:

Dit gaan om die geheim dat ons, die mens, wat in die eerste plek liggaam is, dinge kan maak soos woorde, en met woorde maak ons weer gedigte, en met die maak van gedigte neem ons besit van ander mense, maar ook van klippe, selfs van sterre en raak ons bevry van ons beperkinge, nie net deur die skryf van gedigte nie, maar ook deur die lees daarvan. (bl. 9.)

Om sy digterlike credo nog verder te kompliseer, laat volg hy hiernaas: 'Die medium waarmee die digter (en leser) met gedigte besit neem van ander mense of klippe of bome, is die liefde' (Cloete 2013:9).

Weer eens lê hy onthullende verbande soos volg:

Agter die ...'verwondering, gedigte, woorde, die besit neem van ander mense of dinge, en die liefde, of wrok', keer hy weer terug tot die 'onontsyferbare geheim: die heelal waarin alles met alles saamhang'. (Cloete 2013:9)

Met hierdie uitgangspunt word die mees banale naas 'hemelse' volmaaktes in betekenisvolle verbande saamgedig in sy oeuvre. Trienke Laurie (1997) skryf die volgende insiggewende gedig onder die titel 'Samehang' Vir T.T. Cloete:

\author{
Sneeuvlokkies en sterre laat jy paar, \\ vuurvlieë en komete. \\ ook die silwer draad kan jy verklaar - \\ ons sien die web, maar minder splete. \\ Van erotiek tot erosie - \\ soms selfs speels-verspot - \\ volg ons die samehang in jou poësie; \\ die afdruk van die vinger van God. (bl. 49)
}

Om kommentaar te probeer lewer op Cloete se digterlike procédés, beteken eweneens om jou in 'n netwerk verwysingsvelde van indringende studies te bevind. Die oogmerk van die betrokke ontginning gaan dus om kennisname en benutting van 'n ryk bron van inligting maar met fokus op bepaalde aspekte van die digterlike oeuvre. Dit is verder gestimuleer deur die twee genoemde publikasies Uit die wit lig van my land gesny en Die ander een is ek.

\section{Die misterie van ontkieming}

Dit is die moeite werd om in die lig van Cloete se sterk bewussyn van en aanvoeling vir ' $n$ mistieke vervlegtheid in die skepping wat metafories waarneembaar is, die spore van 'n tema te volg soos wat in die 'Eurinome'-gedig na vore kom. 'Eurinome' is, onder andere, 'n betekenisryke inleiding tot die bundel Heilige nuuskierigheid (Cloete 2007:9).

Een van die mees deurlopende temas in Cloete se oeuvre wat 'n mistieke vervlegtheid demonstreer, is die vrou. Enersyds is daar ' $n$ aanwesigheid in sy oeuvre van verskeie van die mees uiteenlopende vrouefigure - van die bekende Marilyn
Monroe-portrette of 'die mondaine moerige Madonna' (Cloete 1986:33) tot 'die bruidjie wat plaasver in haar eie arms huil' (Cloete 1985:118) of 'magdalena die vroom heilsleërvrou ... deur mukus verlange en larwes bewoon' (Cloete 1986:27). Met die publikasie van die bundels Uit die wit lig van my land gesny (Cloete 2010) en die digterlike prosawerk Die ander een is ek (Cloete 2013), fokus die digter egter op 'n funksie van die vrou wat haar verhef tot ' $n$ 'kroon' van die skepping - sy is 'houer' van die Lewenskiem. Gepaard daarmee word in haar voltrek 'die wonder van die liggaam wat tot "gees" kan transendeer' (1953-vertaling) wat lui:

Soos jy nie weet wat die weg van die wind is, of hoe die gebeente in die skoot van 'n swangere is nie, net so weet jy nie die werk van God wat alles doen nie. (Pred. 11:5)

Volgens Cloete (2013:60) word hier verwys na wat vir die mens onverstaanbaar is, naamlik 'hoe gees en liggaam by mekaar uitkom in die skoot van 'n swanger vrou'. Dat die onsigbare, naamlik gees, uit die sigbare liggaam ontstaan, is ' $n$ vorm van transendering. ' $n$ Soortgelyke proses van transendering behels vir Cloete die sleutelrol wat sy vrou, Anna, in sy lewe speel.

\section{Die komplekse rol van die universele moeder}

Die vrou simboliseer in Cloete se oeuvre by uitnemendheid ' $a$ taste for the secret' om 'n frase van J. Derrida te leen (2001:59). ${ }^{1}$ Volgens die antieke paradysverhaal van die Bybelse kanon, was sy die een wat uitgereik het na 'die vrug wat haar oë sal laat oopgaan' sodat hulle soos God sal wees deur goed en kwaad te ken (Gen. 3:5). Dit impliseer 'n uitreik na misterie. Enersyds het die vrou hierdeur die nouste verbintenis met sterwe en degenerasie verkry. Andersyds word sy aweregs, deur die jongvrou Maria, volgens die Nuwe Testament, as moeder van dié Een wat aan die Goddelike misterie gestalte gegee het, 'n draer van Lig wat ware transendensie en insig kan verwesenlik. Sy skenk inderdaad die lewe aan vlees en bloed, en soos God, maak sy dus 'n mens, maar sy doen dit ook anders as God, as misterie wat in haar maar ook met haar 'gebeur'2. In Cloete se oeuvre is die vrou digterlike 'houer' van hierdie pole - enersyds dié van allesoortreffende Liefde wat lewend maak en laat lewe - 'n Beatrijs van Dante Alighieri (Dante) se Goddelike komedie (kyk Alighieri 1947) - andersyds 'n Medea, Isébel of Marilyn Monroe. Dit was die Marilyn Monroe-gedigte in sy oeuvre wat kreatiewe digterlike vuur aangeblaas het in vele ander digters en navorsers. In die reeds genoemde twee luukse publikasies kom die vrou na vore as Ligdraer, maar daarnaas misterieuse Ligbewáárder.

Die betekenisryke ontwerp en voorkoms van twee bibliofiele uitgawes, naamlik: Uit die wit lig van my land gesny (Cloete 2010) en Die ander een is ek (Cloete 2013) ${ }^{3}$ - albei in die digter

1.Op die voorblad van die publikasie gebruik die skrywer die toepaslike illustrasie van 'n naakte Eva uit 'n diptiek van Lucas Granach 1528.

2.'Daar is lig in die donker voorsegginge en die vrou staan in die middelpunt van daardie lig - haar saad - die Christus (is) die lewensbron van die ganse skepping' (Kroeze 1967:77).

3.Albei uitgawes deur Pooka (Annekie Botha Du Plessis) 
se handskrif, is deur die internasionaal erkende kunstenaar Wim Botha gedoen (Cloete 2013:14). In sy eie oeuvre 'n skepper van indrukwekkende kunswerke wat wit lig uitbeeld, vertolk die betrokke kunstenaar met die keuse van dié voorkoms vir die genoemde publikasies, die sentrale rol van lig/Lig in Cloete se oeuvre.

Die bundel Uit die wit lig van my land gesny (Cloete 2010) dra as opdrag voor in: Vir Anna (in die digter se eie handskrif), wat dit as intiem persoonlik identifiseer. 'n Vrouemetafoor wat hieraan gekoppel word, is die verwysing na die simboliese 'aardmoeder', Anna Perenna. Sy, naas Dante se Beatrijs van die Goddelike komedie, vervul 'n sleutelrol in Cloete se werk. Dit is die ongeskonde Beatrijs wat die DigterSoeker, ná sy konfrontasies met die dieptes en hoogtes van menswees in staat stel om die Eva-uitreik na misterie, maar hier in harmonie met die Goddelike wil, te verwesenlik. Sy is naamlik vir Cloete via Dante, verpersoonliking van Die liefde wat die son beweeg en die ander sterre - met ander woorde, sy dra kosmiese betekenis. Cloete (2013:9) verwys in Die ander een is ek na 'die liefde as 'n sentrale motief vir hom', meer nog, 'as die oorheersende digterlike motivering'. Hierdie liefde waaraan hy deurlopend, sigbaar sowel as impliserend digterlik vorm gee, word vir hom verpersoonlik deur sy Beatrijs, Anna. Om dus in Cloete se werk aandag te gee aan 'n ontginning van simboolvorming van die vrou sowel as die rol en funksie daarvan vir hom as digter, is om spore te volg wat die leser lei na die hart van sy digterskap.

\section{Die vrou as transendentaal}

Een van verskeie gedigte in Cloete (2007:9) se oeuvre wat na aanleiding van 'n skildery ontstaan het, is die gedig 'Eurinome' in die bundel Heilige nuuskierigheid. Die betrokke skildery is van die Duitse skilder Paul Wunderlich (19272010) en dra die opskrif 'Blou torso' (kyk Figuur 1). Dit is onder Cloete se aandag gebring deur die ontvangs van 'n poskaart waarop 'n afdruk van dié skildery verskyn.

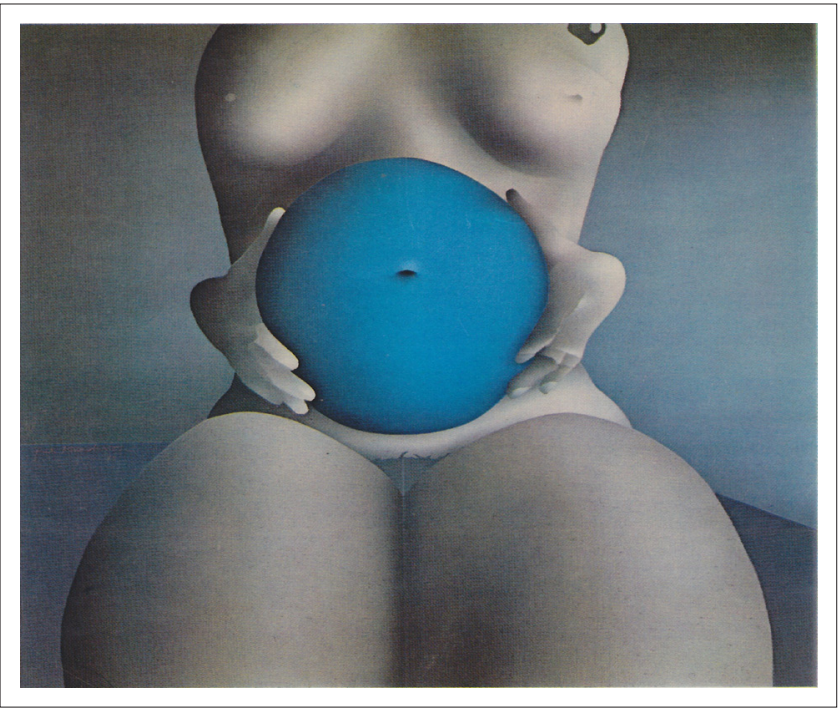

Bron: Poskaart met foto van skildery wat die digter (T.T. Cloete) van vriende ontvang het. FIGUUR 1: 'Blou torso' van Paul Wunderlich.
Hoe vervleg vrouwees is met skepping, transendering, en uiteindelik digterlike skeppingsdrang, vind in hierdie interaksie met skildery en gedig betekenisryke vormgewing. Hennie Aucamp (1981:4) het in sy kortverhaalbundel Volmink verwys na Wunderlich as "n literêre skilder en meestereksegeet. Hy laat metafoor beeld word'.

Die ontginning deur Cloete van die Wunderlich-skildery in 'Eurinome' sluit hierby aan. Die gedig (Heilige nuuskierigheid) lui soos volg:

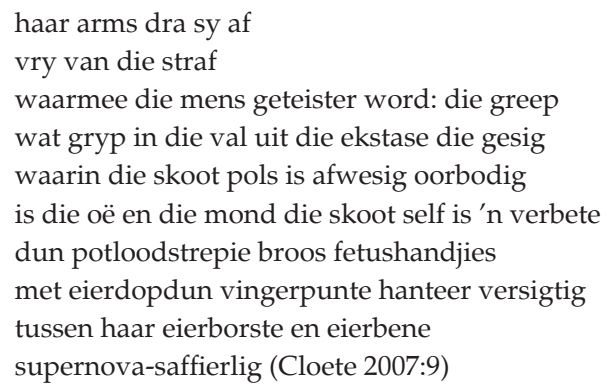

Dit is betekenisvol dat die bundel Heilige nuuskierigheid (Cloete 2007) open met die gedig 'Eurinome'. Eurinome is naamlik die godin van vrugbaarheid wat uit chaos gebore is (ibid:143).

In aansluiting hierby dra die eerste afdeling van die bundel die opskrif 'Nes'. Die vervlegtheid van Cloete se digterlike tekensisteme is ' $n$ uitdaging aan die leser om voortdurend bepaalde fokuspunte te probeer isoleer sonder om perspektief op die digterlike kosmos te verloor.

Soos reeds telkens deur navorsers aangedui, bied Cloete se skepping van die ikoniese gedig - dit wil sê waar vorm en inhoud spieëlbeelde van en aanvullend tot mekaar is - betekenisryke moontlikhede. Die titel van die gedig 'Eurinome', sowel as die aanhaling uit die antieke Akhnaton se 'Lied vir Aton' bo aan die gedig, is sleutels tot mitiese interpretasie. Dit aktiveer oer- en universele konsepte uit die menslike geheue waarom dit in hierdie gedig gaan.

Veelseggend in dié verband is die uitspraak van Joseph: Campbell:

Myths are the dreams of the world. We will not find scientific or historical truth in mythology. But we will find poetic truth. And poetic truth may be all the truth that men will ever know. (Evans 1970:xvii)

Ewe relevant vir die procédés van simboolgebruik en simboolvorming by Cloete is die filosofiese tipering van simbole as 'herkenningstekens' of 'aanskoulike voorstellings van iets anders waarna dit via 'n analogie heenwys, naamlik as metafoor of as sinoniem van tekens' (Kuypers 1966:213).

Cloete pas in sy oeuvre ewe skeppend digterlike ontginning toe van wetenskaplike gegewens, sowel as die onderhawige voorbeeld van mitologiese of simboliese ontginnings en toepassings, of daarnaas kanonieke Bybelse verkennings en interpretasies. 'n Tipering van Goethe se oeuvre deur 
Hermann Broch as 'a prototype of how science and literature could be reunited since both fields were permeated by the infinite' is ewe toepaslik op Cloete se oeuvre (kyk Zellini 2004:10). Broch se verdere motivering van hierdie stelling is desgelyks relevant in verband met die onderhawige Cloete-verkenning:

Goethe was able to fuse scientific interests with artistic goals, by assigning to poetry the power of symbolically evoking the maternal forces of the cosmos - a common root of all polarity (an infinite that precedes all successive comparison between the limit and the unlimited) towards which the aspirations of science were also directed. (Zellini 2004:10)

\section{Simboliese meerduidigheid van die gedig}

Die gedig 'Eurinome' bestaan uit 10 versreëls - 'n mens sou alternatiewelik kon suggereer: 'ontstaan' uit 10 versreëls. Dit is onwaarskynlik dat die digter dit bewustelik beplan het. In sy besinning oor die skeppingsorgaan van die digter, wys Cloete (1987:7) onder andere daarop:' Die gedig is in baie opsigte irrasioneel, ook deurdat hy selfverkose is, sélf voorskrywend is oor hóé en waaróór hy wil skryf'. Hy skryf hierop soos volg oor sy digterlike procédés:

Indien hy 'n gedig geskryf het wat op tien maniere een ding sê, tot taal gemaak het wat nie taal is nie, selfs abstrakte dinge soos tyd en ruimte, selfs veraf dinge soos die sterre, dan is hy tevrede. (Cloete 1984:19)

Wat hy daarmee bereik by die leser, hoef, volgens die digter, niks anders te wees nie as 'dat hy die leser aan die speel sit'. Dit is inderdaad een van die fassinerende moontlikhede en uitdagings vir die meelewende leser van Cloete se poësie. Die gedig 'Eurinome' bied by uitnemendheid hierdie moontlikhede.

Die sterreteken van Virgo (die Maagd) word, veelseggend vir hierdie gedig in verband gebring met 10 . Simbolies verteenwoordig die getal 10 die mite van ewige hergeboorte. 'n Woordeboek van simboolvorming verwoord hierdie mitiese proses soos volg:

By sending us back to the point of departure or square one, the number 10 paves the way for regeneration, a continual process of rebirth, since it heralds the end of a cycle. It allows us to be reborn by adhering to the cycles of life. (Colin 2000:393)

Volgens hierdie beginsel rig die laaste versreël met sy verwysing na 'supernova-saffierlig' die leser weer op die beginreëls van die gedig wat lui: 'haar arms dra sy af / vry van die straf'. Dit vestig die aandag op 'straf' as duister teenpool van 'saffierlig' en in dié verband, 'n berowing van die vryheid tot ontkieming. In die skildery word die baarmoeder-eier omvou deur koesterende 'eierdopdun vingerpunte' wat versmelt teen die res van die torso.

Die gedig maak dié kontras sigbaar, selfs sonder die visuele ver-beelding van die skildery. Die gedig skep as't ware ruimtes (oop plekke) vir die misterie van 'die skoot', 'vry van die gesig / waarin die skoot pols'. Binne die verband van hierdie gedig sou dié 'oop plekke' getipeer kan word as 'misterieruimtes'. Die gekoesterde skoot word getransendeer tot iets bonatuurlik - selfs vry van beperkende of inperkende emosie, wat uit gesigsuitdrukkings afgelei kon word. Dit is dié lewensvorm wat slegs met hipersensitiwiteit gevoel eerder as gesien word. Die digter verwoord die wonder wat uit dié fokus op die skeppende 'baarmoeder' ontplooi, soos volg:

Die onpeilbare is dat daar uit hierdie skelet, hierdie liggaam van been, vlees en bloed transendente kan ontstaan soos taal ('n fundamentele transendent) en simboliek, iets soos moraliteit, spiritualiteit, geregtigheid, eerlikheid, die wiskunde, en hoop ('n futuristiese transendent, gerig op wat nog moet gebeur) en die uitnemendste van alles: die liefde. (Cloete 2013:51)

In die misterie wat deur die gedig via die skildery gekommunikeer word, resoneer die volgende waarneming van die digter:

Een van die wonderlikste fenomene is dat ons onsself kan transendeer tot self-bewussyn, tot 'n 'self' wat na hom- of haarself kan kyk sonder 'n spieël sóós in 'n spieël, wat oor homof haarself kan nadink, 'n meta-self, wat kan dink oor sy/haar dink. (Cloete 2013:52)

Relevant vir die meerduidigheid van die gedig is hierop die digter se verwysing na 'die gedig as ... een van die kragtigste en mees magiese kragte tot selftransendering'. Hy verwoord hierdie verband soos volg: 'Die lieflike veelkleurige vlinders van die liefde, die lieflike fladderende skoenlappers van die poësie kom uit 'n misterieuse verseëlde koepel', vergelykbaar met die baarmoeder (Cloete 2013:53). Die verwysing na die 'veelkleurige vlinders van die liefde' antisipeer hier as't ware reeds op simboliese vlak die proses waarom dit ten diepste gaan, naamlik die feit dat 'vlinders simbolies die siel se reis deur lewe en dood en hemel, met uiteindelike opstanding as rigpunt verteenwoordig' (Fontana 2010:84). In die lig van hierdie verwysingsmoontlikhede word dié baarmoeder as misterie 'n meerduidige digterlike simbool. Die digter kyk via die simbool in ' $n$ misterie van selftransendering. Dit is vergelykbaar met die fisieke geboorte en dit funksioneer as simbool van die ontkieming van die gedig.

In Die ander een is ek wys die digter onder andere daarop 'Gedigte skryf, is saad maak, saad wat in ander harte saad kan skiet' (Cloete 2013:27). Hierop word uitgebrei onder die veelseggende opskrif 'Tot die vermenigvuldigde lewe ontroer':

As daar sprake is dat die een mens die ander mens of ding kan word, moet ' $n$ mens begin by die vrou. Die vrou is die menslike figuur wat ander lewens biologies voortbring, nuwe lewe skep, nuwe mense 'weef' in haar liggaam. (Cloete 2013:28)

Die digter brei selfs verder hierop uit:

Dit gaan om die latente talente wat die vrou, as die wesentlik vrugbare, vrugbarende figuur, in die man aktualiseer; dan word die potensiële in die man gekiem en verwerklik. Sy word 'n selftransenderende agens. (Cloete 2013:51)

Vir die digter Cloete het dit ook fisiek 'n simboliese voltooiing en vervolmaking beteken deur die totstandkoming van sy 
gesin van sewe - 'n metafoor vir volmaaktheid waarin aarde en hemel in die syfers 3 plus 4 figureer (drie vroue en vier manlikes, vgl. 'Harba lori fa', Cloete 1980:11). In Die ander een is ek wys hy byvoorbeeld in 'n vergelykbare verband daarna dat selftransendering deur die liefde ook 'n fisieke werklikheid is (Cloete 2013:15).

Insiggewend vir Cloete se digterlike ontginning van die aanwesigheid van die vroulike stelreël in die skepping, is die volgende mitiese uitgangspunt: 'In creation myths the female principle is the female partner in the great cosmic act of love which resulted in the birth of the earth and of all peoples' (Thames \& Hudson 1997).

Cloete (2013) sluit aan by dié universele ver-beelding wanneer hy in Die ander een is ek daarop wys: 'Die vrugbaarheidsbeginsel was nog altyd in mites en beelde 'n vrou ... In die Out-of-Africa-teorie word verwys na die vrou Eva wat die oorsprong van homo sapiens is'. Hy haal uit Wikipedia aan:

Mitochondrial Eve is ... the woman who is defined as the matrilineal most recent common ancestor (MRCA) for all currently living humans. Passed down from mother to offspring, the mitochondrial DNA (mtDNA) is now found in all living humans: every mtDNA in every living person is derived from hers ... (Cloete 2013)

Selfs in die Ou-Testamentiese kanon word die SkepperGod in Psalm 131 by geleentheid metafories voorgestel as moeder, 'n vrou. Cloete (2013) haal verder soos volg aan: 'Mitochondrial Eve is believed to have lived about 170,000 years ago in Africa'.

Weereens roep dit Eva se uitreik 'om soos God te wees' in herinnering: sy funksioneer as simboliese oeroorsprong ... sóós die Goddelike Skepper. Cloete (2013:248) se holistiese benadering kan ook afgelei word uit die volgende opmerking: '... snaaks dat die wetenskaplikes soos die digters nie sonder metafore kan klaarkom nie'.

\section{Gedigvorm as baarmoeder van betekenispotensiaal}

Daar is reeds gewys op Cloete se gebruikmaking van die spasies of 'oop holtes' tussen woorde in versreëls waarna hy verwys as 'luisterholtes'. Geggus (1961:29) het in haar studie, Die wit in die poësie, eweneens aangedui 'hoe die tipografiese wit (in die gedig) sélf 'n versreëlkonstituerende element in die poësie kan wees'. Die leser moet hom of haar egter telkens daarvan vergewis wat elke afsonderlike voorbeeld in 'n gedig ver-beeld, aangesien die betekenis daarvan nie eenvormig interpreteerbaar is nie. Die funksie van ' $n$ voorbeeld word bepaal deur die verbande in elke unieke gedig.

In die gedig 'Eurinome' kom die luisterholtes voor in die middelste vier reëls wat weerskante 'omvou' /'omarm' word deur drie reëls daarsonder. Hierdie middelste vier versreëls word omarm deur versreëls wat verwys na 'n 'greep', wat kontrasterend staan teenoor die koesterende omarming van 'fetushandjies'. Dit is asof die gedig intern kommunikeer tussen versreëls onderling wat dui op die hegte taal- en vormstruktuur van die gedig. Die opvallende herhalende g-wrywingsklanke in die drie versreëls wat volg op die reël 'vry van die straf', kontrasteer met die broos fetushandjies, eierdopdun vingerpunte, eierborste en eierbene - elkeen simbool van broosheid en breekbaarheid.

\section{Die son as kosmiese eier}

Die aanhaling uit Akhnaton se 'Lied aan die son Aton', as inleiding tot die gedig 'Eurinome', plaas dit in betekenisvolle verbande in die betrokke bundel Heilige nuuskierigheid, en eweneens in die breër Cloete-oeuvre. Heel voor in die bundel Uit die wit lig van my land gesny word die naam Anna teruggevoer na'n simboliese oorsprong wat soos volg lui: 'the name (anna) may be Gr., "grace", or Sanscr. "ana" = "mother"... one of the names of the Universal Mother (Anna Perenna)' (Cloete 2010). Die verwysing na die oermoeder word opgevolg deur die ewe betekenisryke verwysing uit Dante se Goddelike komedie, na: 'Die Liefde wat die son beweeg en die ander sterre'. Laasgenoemde tipering kom ten slotte weer ter sprake.

Dat dié gedig ontstaan het uit digterlike verwondering oor die misterie van die vroulike baarmoeder, word onder andere soos volg verwoord in die gedig met die titel 'vleis' wat begin met die versreël: 'die wêreld is vol verbasings'. Hierop volg:

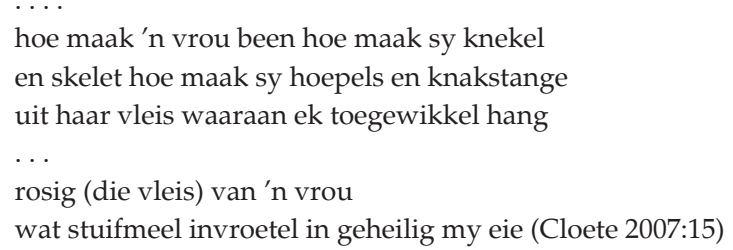

Die feit dat die vrou haar arms 'af' dra volgens die eerste versreël van 'Eurinome' impliseer dat ' $\mathrm{n}$ wonder in haar voltrek sonder 'menslike handvaardigheid'. Hiervan getuig die slotbegrip van die gedig: 'supernova-saffierlig'. In die lig daarvan dat die son so 'n deurlopende simbool in Cloete se oeuvre is wat veral ook in verband met digterlike verbeeldings van Anna voorkom, word die aandag gevestig op die verband tussen die lewe- en die sonsimbole. Die samestelling van 'supernova' en 'saffierlig' impliseer'n ligwonder. 'Supernova' verwys na 'n nuwe ster van uitsonderlike helderheid wat selfs gedurende daglig sigbaar is - 'n wetenskaplike gegewe, terwyl 'saffierlig' weer 'n metaforiese, mitiese element impliseer (Kruyskamp 1961:1987). Die saffier staan byvoorbeeld bekend as ' $n$ hemelse edelsteen, wat embleem is van hemelse harmonie, vrede, waarheid en klaarheid (Tresidder 2004:434). Dit bring vrede en vreugde van gees en maak ontvanklik vir skoonheid en intuïsie. Dit is bykomend die verjaardagsteen van September, die negende maand, en is simbool van gesuiwerde denke (Cloete 1996:27). Telkens blyk die vervlegtheid en die meerduidigheid van Cloete se beeldspraak.

Die hele gedig, soos die skildery, getuig van 'n na binne gekeerdheid en van misterie, vergelykbaar met die 
mitologiese Maagd-figure wat getipeer word as: independent personalities in their own right, not just consorts or pale reflections of their mates...

\section{In dié verband vervolg Chetwynd (1993b):}

It was her individuality and psyche that (is) intact. She is true to herself and the one who preserves her inner integrity... For the man, the Virgin is his Anima, which the imagination so often clothes in pure white. On the great universal scale, the Virgin is the pure unsullied womb of nature - empty space, the immaculate source of all things, the Divine itself ... the Primordial zero, the World Egg, unbroken, empty space, the circle of the sky as if drawn by the radiant morning and evening star sweeping around its course from horizon to horizon ... (p. 225)

Hierdie uitgangspunt word deur die opvolgende gedig met die titel 'eier' onderskryf, wat begin met die versreël: 'Daar was net een eier en dié was vol kuit' (Cloete 2007:10).

Dat die maagdelike vrou as digtersanima in Cloete (2013) se oeuvre figureer, spreek uit die volgende uitbundige slotreëls:
ek steier uit dié eier
uit dié eier vol geboortevreugde 'n nat kale kuiken onvas
met my oopgesperde donsvlerke kieriedunbeen
barre toon op 'n brandende aarde tas-tas
met my dun gesig teen ' $n$ ver gloeiende lig
deur jellies en jellies kuit na 'n glibberige daarheen
wat bestaan het voor dit waar was (bl. 13)

\section{Van Aardmoeder tot Sonvrou}

In aansluiting by die reeds genoemde mitologiese verwysings in die gedig 'Eurinome', sowel as die veelseggende aanhaling deur die digter uit Akhnaton se 'Lied aan die son' bo aan die gedig, tesame met die verwysing na Anna as 'uit die wit lig van my land gesny', is die gedig 'vrouson' 'n verdere betekenisryke skakel (Cloete 2007). Dit sluit ook aan by die 'Son' - alternatiewelik 'Lig'motief as 'n belangrike leitmotief in die Cloete-oeuvre. Fisies gesproke is sonlig lewegewend terwyl Lig in vergeestelikte sin verheerlikte lewe impliseer. Die eerste gedig in sy eerste gepubliseerde bundel Angelliera (Cloete 1980:1) dra byvoorbeeld die titel: 'Sonneblom'.

Bykomend gaan die gedig oor 'n tweede genoemde sleutelmetafoor, naamlik bevrugting, soos ook in 'Eurinome' ontgin. Dit kan afgelei word uit die reëls:

$$
\begin{aligned}
& \text { die sonneblompit } \\
& \text { weet die sak saad } \\
& \text { weet die sonneblomplant } \\
& \text {... weet die saad binne wit } \\
& \text { buite swart ... (Cloete 1980:1) }
\end{aligned}
$$

Die sonneblom is ook simbool van vrugbaarheid, potensiaal en hernuwing na aanleiding van sy dig met saad gevulde 'gesig' wat na die son draai. (Fontana 2010:46)

Die volgende simboolwaardes van die son is relevant vir die ontplooiing daarvan as sleutelmotief in die Cloete-oeuvre:
The sun is presented as the visible embodiment of Light and of the highest cosmic intelligence ... and of the life-giving principle. Its daily renewed ascent and descent made it a symbolic precursor of resurrection as well as generally of every new beginning. (Matthews 1993:186.)

Die digter skryf soos volg na aanleiding van Die ander een is $e k$ 'n gedig vir Anna, wat reeds in die bundel Driepas (Cloete 1989:17) verskyn het en waarin die Lig- en of sonassosiasies met haar prominent is:

Skielik, vanuit ons agterplaas in 'n klein plattelandse dorp waar sy haar hare gewas het, het ek die hologram deur haar gesien en het sy 'n sprong gemaak in die heelal in en my agterna gelok. (Cloete 2013:249)

Versreëls uit die gedig lui soos volg:

op die hoogson middelweek het dit gebeur

jy het sonder voorwendsels by my opgedaag

waar onder my graaf en vurk die grond geur

het jy gekom en die voëltjies en insekte opgejaag

soos 'n wit slank reier

...

daar was vonk in jou rosige hare

'n gloed in jou dun rok

jou ooglede was soos rose roosblare

iets in die tuin het amok

gemaak jy was onvervul ek was vol

ons was 'n raserny

die son was op hol

'n tol 'n hygende blom vir ' $n$ tierende by

(Cloete 1989:17)

Die gedig eindig met volgehoue sonbeeldspraak:
die vulkane het 'n leeftyd trug al bedaar
tog onthou ek sedertdien
hoe in wit gloeiende sonlig vir mekaar
toeoog mens sterre sien
(Cloete 1989:17)

Hieruit blyk reeds dat die son-/ligbeeldspraak in die vroeër oeuvre met betrekking tot sy 'sonvrou', Anna, die Beatrijs-parallel geantisipeer het. Dante se Goddelike komedie is soortgelyk vooraf gegaan deur 'n verkenning van die ontkiemende Liefde in sy La Vita Nuova. A.N. Wilson (2011:66) skryf soos volg oor die simboolvorming van Beatrijs in Dante se Goddelike komedie: 'His (Dante's) childhood self, falling in love, and the girl-object of his passion - are frozen into symbol immediately by his seeing them in terms of numerological mystery'.

Dié proses kan ook in Cloete se oeuvre onderskei word.

Betekenisvol is dus die feit dat Cloete se Anna-gedigte uit die staanspoor in die teken staan van 'n metaforiese Ligbron en liguitstraling. In die genoemde 'vrouson' - gedig word sy selfs eksplisiet geïdentifiseer as 'my sonvrou'. Die gedig lui:

die lig kry sy krag uit die hare

van 'n vrou die son is hare

sy was haar hare in supernova-blou lig sy gooi

haar kop wielend agteroor sy strooi hoepelslierte rooi

superprominensies uit sy skud orkane los

parabole deur die groot ooptes van die kosmos

sy my sonvrou uit haar turkoois harebos

(Cloete 2007:17) 
In die lig hiervan is dit veelseggend dat sy as die ligbron geïdentifiseer word en nie andersom nie - die gedig word ingelei met die versreëls: die lig kry sy krag uit die hare / van 'n vrou die son is hare ...

Die verwysing na 'supernova-blou lig' roep die 'supernovasaffierlig' op van die 'Eurinome'-gedig. Dit impliseer die numineuse kontrasterend met die versreëls: ... sy strooi hoepelslierte rooi / superprominensies uit sy skud orkane $\operatorname{los} \ldots$

Sy word simbool van kosmiese krag en mag maar ook van boaardse Lig. Telkens roep dit die Eva-uitreik na bonatuurlike misterie op, wat ten diepste gaan om transenderende Lig gepaardgaande met Insig, sowel as bonatuurlike skeppingsvermoë.

\section{Die 'droomvrug'-tyd}

In gesprek met die rol van die sogenaamde 'oereier'-mite, volg die gedig 'Dali' (2007:16) ná 'Eurinome', hoewel dit 'vrouson' vooraf gaan. Die gedig is weereens in gesprek met 'n skildery, in dié geval van die genoemde skilder Salvador Dali. Dit dra die onderskrif: 'Persistence of memory' en bestaan uit horlosies in die vorm van 'n lopende eier oor 'n droë tak in 'n gestroopte landskap. Veelseggend is die eiermetafoor in dié verband wat aansluit by die baarmoeder-eiermotief van die Wunderlich-skildery. Die Dali-skildery word bestempel as simbool vir dié skilder se oeuvre as geheel. Insiggewend vir Cloete se interaksie daarmee, word na aanleiding van Dali se kunswerk gewys op 'his concern for the "poetic content" of art - arising from emphasis upon subject matter and evocative use of the formal elements of composition.' (Rothenstein 1972:1240).

Die Dali-skildery dra die onderskrif 'die hardnekkigheid van onthou' ('Persistence of memory', in Weyers 2005:28) en word veelseggend as onderskrif gehandhaaf by die opskrif van die Cloete-gedig (2007). Dit lui soos volg:

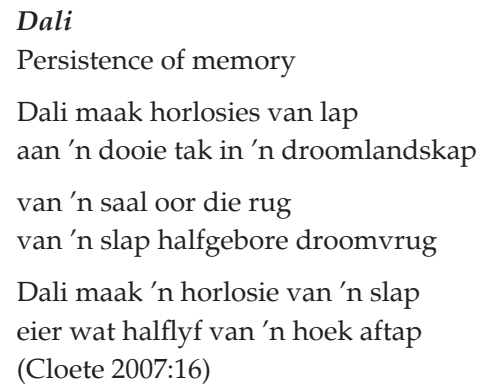

Die horlosie as instrument vir die meting van tyd word in skildery en gedig gerelativeer deur daarna te verwys as 'horlosies van lap' en veelseggend "n slap eier'. Tyd en spesifiek afgemete tyd wat deur die horlosies verteenwoordig word, kan in dié verband eweneens gelees word as 'n skeppende houer of 'baarmoeder' - in dié geval 'n houer vir 'onthou'. Wat egter in skildery en gedig gesuggereer word, is dat hier sprake is van 'n onstabiele 'houer' wat nie sinkroniseer met die 'vrug' nie - in dié geval die 'onthou' wat in en uit tyd gebore word maar wat tyd misvorm of omvorm deur 'n eie loop te neem. Figuurlik gesproke suggereer die beeldspraak van die skildery: 'tyd loop uit' of 'verloop' waardeur 'n surrealistiese atmosfeer in 'n verlate oeromgewing geskep word. Dali se motivering vir die beeldspraak van sy skildery wat eweneens 'n interaksie van wetenskap en kuns weerspieël, lui soos volg:

Dali's soft clocks were described by him as symbols of the fourdimensional space-time continuum of the theory of relativity. The theory demonstrated that each body has an innate time of its own that is dependent on its movement and its state of energy, not on time measured by clocks, as clock time adapts to energy conditions. In comparison with the eternity of the landscape, the purely technical measurement of time is ultimately without value or importance. (Weyers 2005:28)

In twee aaneensluitende gedigte met die titel 'la durée' skep Cloete betekenisryke agtergrond vir dié Dali-gedig met eweneens 'n relativering van die 'vrug/vrugte' van tyd. Die onderskeidende newetitels van die twee gedigte naamlik 'Die oorrompeldes' (Cloete 1985:39) en 'Die veroordeeldes' (ibid:113) werp verder lig op die digter se ontginning van die surrealistiese kwaliteit van die 'tydeier', wat veelseggend ook 'n 'oereier' is in terme van menslike begrip. Die genoemde twee gedigte kom voor in die bundel Allotroop wat die digter bestempel het as sy 'pynbundel'. Dit gaan dus hier om wat beskryf kan word as 'pynlike onthou' soos die betrokke genoemde publikasies verder getuig. Enkele strofes uit die tweede 'la durée'-gedig lui:
dit het nou daarvan gekom
iets kosbaars en besonders
oё wat sonneblomme blom
wat inhalig oop is vir wonders
wat glasblind staar bysiende maar gester
helder gerig op die verste ver
(Cloete 1985:113)

Die genoemde gedig eindig soos volg:
die lang ure wat $\mathrm{u}$ uitmeet
een vir een oordadig en gul
wat $u$ vir ons leeg gereed
hou om onversadig in te vul
met laaste oë wat oerelementêr
verbaas lank vir 'n laaste sien oopsper
(Cloete 1985:113)

Die 'duur' van onthou is by uitnemendheid disjunktief met betrekking tot tydsduur wanneer dit teenstellings van geboorte, groei, aftakeling en dood raak. Dit word simbolies soos volg verwoord: 'The cycle of time (as a binding circle) affects the TRANSFORMATIONS of life. Often the changes cannot be hurried, any more than the Spring can be brought forward' (Chetwynd 1993a:402).

Dat Cloete se waarnemings en verwondering oor die misteries van tyd en veral sogenaamde afgemete tyd om verskillende redes aansluiting vind by die aangrypende skildery van Dali, blyk verder uit die volgende versreëls uit die later gedig 'voorvereiste':
in die duur wat skrikwekkend méér word
is in die kort
afgestane tyd vir my ander lewens ingepas
in myne 
... dit het my kleingekry

'n onsyferbare tyd in die tyd wat steeds uitdy...

(Cloete 2007:104)

Daar word simbolies verwys na die misteries gekoppel aan tyd as: 'The cycle of time (as a binding circle) (which) affects the Transformations of life'. Die primêre funksie van die simbool is naamlik '... to reunite the shattered fragments of life; in an instance of time... to restore the experience of the original unity of time' (Chetwynd 1993a:402).

In die lig van die saamhang van die aardmoeder-simboliek met die onafwendbare verloop van tyd tussen die siklusse van geboorte en dood, verbeeld gedig en skildery die misteries van menslike konsepte en belewenis van tyd.

Die volgende opmerking van J. Kristeva (1993) na aanleiding van haar studie van Marcel Proust se sleutelwerk in verband met die kompleksiteit van prosesse van tyd en onthou, Remembrance of things past (1922-1931), is eweneens van toepassing by die verkenning van die genoemde verwikkeldhede van tyd en onthou in die Cloete-oeuvre:

Proust ... seeks to understand Being by exploring the obscurities of Time... he proposes a psychic universe of the maximum degree of complexity as the favourable location - the place of sacred communion where lovers of reading can meet. (p.6)

In die bundel Idiolek het Cloete (1986:104) insiggewend verwys na 'die heilige tydelikheid van die tyd' - 'n oënskynlike maar relevante teenstelling wat desgelyks dui op die kompleksiteit van enige vorm van tydsontginning.

In ' $\mathrm{n}$ ontredderingsproses wat ontstaan het met die lyflike sterwe van die digterlike anima Anna, die meervoudige vrugbaarheidsimbool by uitnemendheid, word in die gedig '-kunde' aangrypend verwys na 'n steriele 'vals' son, die tydhouer, wat sy lewegewende funksie verloor het. Die betrokke versreëls lui: 'die son lê soos 'n stywe onvrugbare / dooier op die horison onmagtig om te sak ...' (Cloete 2011:137).

Dit verwoord die ervaring van die stol van tyd wat gepaardgaan met die beëindiging van lewe - dit word 'n steriele 'eier' en 'n ver-loopte 'horlosie'. Weereens bring dit die begin van ontkiemende lewe, soos deur die baarmoeder'eier' in 'Eurinome' gesimboliseer, en daarnaas onstabiele horlosietyd, soos deur Dali versimboliseer deur middel van die 'horlosie-eiers', in sinvolle verband met mekaar. Die ronde geel eierdooier roep bykomend ook sonsimboliek op.

\section{'n Transenderingsproses}

Dit is nie moontlik om die talle aaneenskakelende son-/ ligsimbole in Cloete se oeuvre binne die kort bestek van dié verkenning aan te dui nie. Die bundel Uit die wit lig van my land gesny werp telkens lig daarop. Dit is betekenisvol vir die wyse waarop die basiese metafoor van bevrugting, soos versimboliseer in 'Eurinome', deel/die kiem word van voortgaande, evoluerende, kosmiese skeppingsgebeure. Nie slegs aan vleis word die lewe geskenk nie, maar misterieus ook aan simboliese bo-aardse Lig as verblindende, maar onbeskryflike skoonheid. Wat deur die baarmoeder voortgebring word, blyk dus meer as vleis te wees. Dit aktiveer vergeestelikte aktiwiteit wat in verband gebring kan word met prosesse van transendensie wat by uitnemendheid aanleiding is tot digterlike skeppingsvermoë, soos weerspieël in die Cloete-oeuvre.

In die reeks gedigte 'roetes op soek na jou' wat tot stand gekom het ná Anna se dood, word weer 'n verband gelê deur die 'Eurinome'-gedig wanneer na haar verwys word as 'my duifie sonder gal', volgens die digter 'n gebruiklike verwysing van haar kinders na haar (Cloete 2010:16, 104). As nota by Eurinome word deur die digter die volgende toepaslike verwysing in dié verband gegee: 'Eurynome, goddess of fertility, having risen from Chaos ... assumed the form of a dove, and laid the Universal Egg ... The universe issued from it' (Cloete 2007:143).

Die duif is 'n tipies transendentale simbool. In die Christelike kanon figureer die duif as goddelike boodskapper en simbool van vrede. Die wit duif is ook simbool van die Heilige Gees wat met die aankondiging van Christus se Goddelike oorsprong en sending tydens sy doop verskyn het (Fontana 2010:75).

\section{Misteries van hergeboorte}

Een van die misteries van die Anna-digter-verhouding in Cloete (2013:94) se oeuvre, is dat sy self, reeds fisiek terminaal siek, vir die digter 'gebore' word in onbeskryflike skoonheid. Terwyl hy na haar kyk in haar 'reeds langsaam sterwende liggaam' neem die digter dit soos volg waar:

Ek het gesien hoe byna deurskynend mooi sy is, hoe daar 'n nuwe skoonheid uit haar ontstaan, soos 'n vlinder gebore word uit 'n kokon. 'n Onbeskryflike nuwe mens. Ek het onthou dat Frankl gesê het ons beeldspraak is verkeerd: Doodgaan is nie 'n aan die slaap raak nie, dit is 'n wakkerword. (Cloete 2013:94)

Hierin figureer weer die betekenisryke vlindersimbool vervleg met geboortesimboliek.

Interpreterend blyk die sublieme simboliek van hierdie digterlike waarnemings terugskouend te wees (2013:95): 'Die sterwende Anna ... het vir my 'n vlinder geword wat rondvlieg in my geheue, in my herinnering en mymering'.

Dit het geblyk dat die vlinder die dood sowel as opstanding en onsterflikheid simboliseer (De Vries 1974). Cloete (2013:95) verwys hierna as 'kollektiewe transendente'. Die digter voer dié verband nog verder deur sy eie interpretasie by wyse van die volgende waarneming: 'Die vlinder is ook so vroulik!' In die simboliese voorstellings van die vrou word sy nie net as skepper en vrugbaarheidsfiguur gesien nie, sy simboliseer tewens die dood. In dié verband haal Cloete weereens aan uit Mark O'Connell \& Raje Airey: 'Many signs and symbols in nature are taken as omens of birth or death'.

\section{Cloete se interaksie met die Goddelike komedie van Dante}

In 2011, vier jaar na die fisieke dood van Anna, verskyn Cloete se bundel onversadig. Weereens, in aansluiting by 
reeds genoemde deurlopende metaforiese en simboliese tendense in die Cloete-oeuvre, word die tiende afdeling in dié bundel voorafgegaan deur die opskrif waarmee Dante se Goddelike komedie eindig, naamlik Die liefde wat die son beweeg en die ander sterre. ${ }^{4}$ Ook in Die Goddelike komedie neem die simboliese gebruik van getalle 'n sleutelplek in. Cloete se omvattende interaksie met hierdie universele teks kan in die huidige verband slegs rakelings ter sprake gebring word.

In William Anderson (1983) se publikasie Dante the maker word die sentrale funksie van 'wit lig' in Dante se Goddelike komedie soos volg aangedui:

The fundamental image of the Commedia is light, known in its essence (luce) as radiance (raggio), and as reflected splendour (splendore), creating dramas of colour, shadow and darkness. Beatrice is called by Virgil 'the light between the truth and the intellect' (Anderson 1983:416). (H)e regained through her the essential nature of poetry, its preservation of the mystery of things. (p. 346)

Die twee publikasies van Cloete, naamlik Uit die wit lig van my land gesny (2010) en Die ander een is ek (2013), vertolk deurlopend die genoemde temas en tendense in sy oeuvre. Dit stel die tema van 'wit lig', met al die konnotasies daaraan gekoppel in die bundels, voorop. Simbolies gesproke is wit nie slegs die kleur wat verwys na lig, suiwerheid en volmaaktheid (alternatiewelik heiligmaking) nie. Dit word ook geassosieer met die absolute, verwysende na begin en einde sowel as die vereniging daarvan. Dit figureer in sommige kulture as teken van rou. Met Christus se verheerliking op die berg word sy verskyning soos volg beskryf deur Mattéüs (Matt. 7:2): 'En Hy het voor hulle van gedaante verander, en sy aangesig het geblink soos die son, en sy klere het wit geword soos die lig' (Matt. 17:2). Teenoor die kleur rooi wat simbolies as manlik geïnterpreteer word, word wit geassosieer met die vrou (Matthews 1993:214). Naas talle direkte verwysings na Dante en sy Goddelike komedie, toon Cloete se oeuvre merkwaardige paralelle met Danteaanse persepsies, soos ook in dié geval van die opvallende beklemtoning van wit en lig.

Die digter herken in sy 'Anna Perenna' die Beatrijs-figuur in sy uitreik na volmaaktheid en volkome sig en insig soos dit soortgelyk ontwikkel in Dante se Goddelike komedie (kyk Figuur 2).

In Canto 22 reël 105 van die Paradiso (Alighieri 1977:251) getuig Dante van Beatrijs: 'My nature vanquished by her power anew'. Toynbee (1978:72) interpreteer die Beatrijs-figuur onder andere soos volg: 'Allegorically, Beatrice represents ... the divine science, which leads man to the contemplation of God, and to the attainment of celestial happiness'.

Die gedigte 'Eurinome' en 'vrouson' waarin die twee sleutelmotiewe, naamlik die vroulike vrugbaarheidsbeginsel en lig of Lig figureer, is sprekende voorbeeld van die Cloeteoevre se deurlopende intertekstualiteit met Dante se Goddelike 4.Volgens die Afrikaanse vertaling van Delamaine du Toit (2002:407).

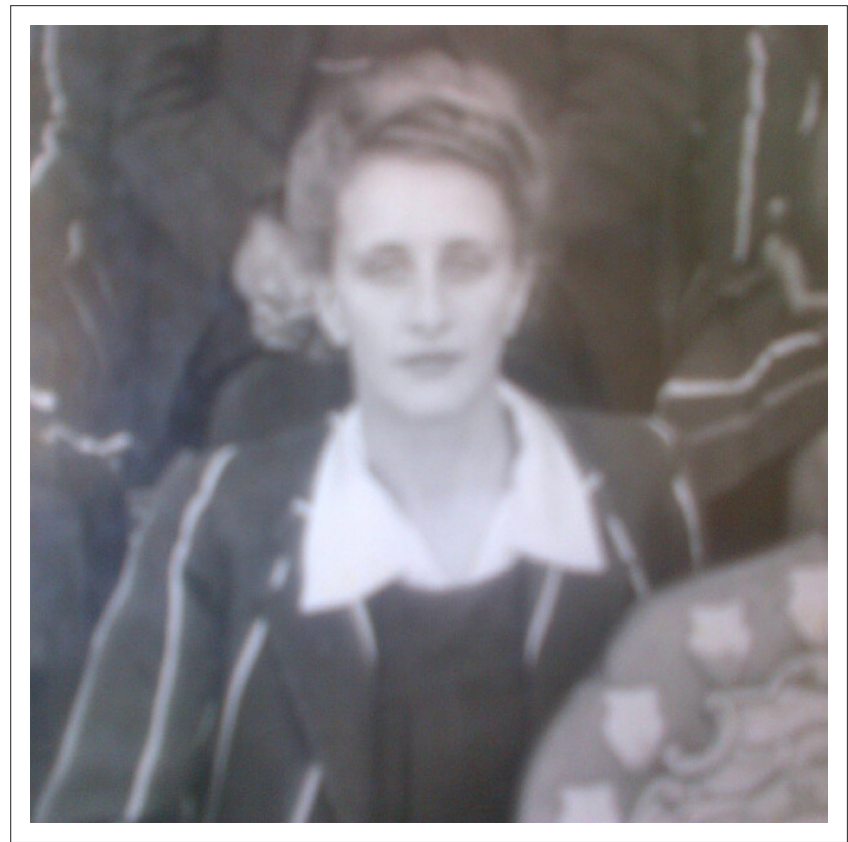

Bron: T.T. Cloete

FIGUUR 2: Anna as jong vrou.

komedie. Dit ontwikkel onder andere deur die wyse waarop 'n vereenselwiging van Anna en Beatrijs, beide as kosmiese simbole, afgelei kan word. Vir Cloete (2013:246) bestaan die fokus op die transendentale rol van die vrou, soos in die geval van Dante se Bice Portinari, daarin dat sy 'uitgroei tot 'n simboliese vroulikheid'. Dit is belangrik om te let op die betekenis van 'transendeer' naamlik dat dit gaan om wat 'uitreik bo die sintuiglik waarneembare' (De Villiers et al. 1985:528). Marcel Proust (in Stern 1989:83) het in 'n artikel oor Flaubert daarop gewys: 'Metaphor alone can give a kind of eternity to a style'.

Die digter verwoord hierdie vroulike rol as digterlike transendent in Die ander een is ek soos volg:

Nie net deur aanwysbare handelinge en insidente nie, maar eerder op nie-aanwysbare, nie-konkrete, onsienlike manier en op 'n permanente, durende grondslag maak 'n Bice, of ana van jou (as man en digter) 'n ander een ... Deur die ana word jy gekiem tot iemand anders en meer as jouself, en het jy bopersoonlik en transendenteel die vroulikheid as sodanig lief, die vroulike beginsel wat teruggaan tot by Gaea, Eurinome, tot by 'das Ewig-Weibliche' uit die 'Chorus Mysticus' aan die einde van Goethe se Faust, soos die Liefde met 'n hoofletter in Dante se Heilige Komedie in die slotvers staan. (Cloete 2013:251)

Aansluitend weereens by die Eurinome-gedig gaan hy voort:

Dit gaan om die latente talente wat die vrou, as die wesentlik vrugbare, vrugbarende figuur, in die man aktualiseer; dan word die potensiële in die man gekiem en verwerklik. Sy word 'n selftransenderende agens. (Cloete 2013:251)

Twee betekenisvolle tendense wat voorkom in die gedigte van Cloete wat saamhang met die verwerking van Anna se dood, is enersyds die intensiverende spel van Lig en donker en daarmee saam 'n geïntensiveerde waarneming van die uitspeel van kosmiese patrone. 
Reeds in die gedig 'Anna' egter, was sy van kosmiese betekenis in 'n digterlike ontginning van die aarde en sy vele uitdrukkingsvorme of 'stemme'. Dit blyk uit die volgende reëls uit dié gedig onder haar naam uit die vroeë Met die aarde praat: 'Kyk ek na die melkweg in die gras, / in die water, na die boog / van die aarde, altyd iewers is jy ingepas' (Cloete 1992:95).

\section{Vergeestelikte suiwering - Sublimering}

Wilson (2011) skryf in sy publikasie Dante in love verhelderend soos volg oor die mistieke proses van gesuiwerde liefde wat geïntensiveerde en getransendeerde sig meebring:

Without rejecting his experiences of love, as carnal lover, as friend, as father, as husband, he (Dante) is guided by Beatrice, who has become an embodiment of Divine Love - Grace - the spokesperson of the Love which moves the sun and other stars. (p. 252)

Veelseggend vervolg Wilson (2011) dan:

This process of transformation will take him the rest of his life, both to turn into a work of literature and to attempt to accomplish in his own person. It is nothing less than the journey of sanctification in which none perfectly succeed and few get anywhere near. (p. 252)

Dat 'n soortgelyke proses by Cloete geïdentifiseer kan word, kan veral afgelei word uit die genoemde publikasies Uit die wit lig van my land gesny (2010) en Die ander een is ek (2013).

Lig word tradisioneel simbolies vertolk as gees (Cirlot 1982:187). Dante beskryf in Canto XXX:100-103 van sy Paradiso sy transformasie in dié verband soos volg:

Daar bo is 'n lig wat die Skepper

sigbaar maak vir elke skepsel

wat in die sien van Hom sy vrede vind;

en dit strek in so 'n wye sirkel uit

dat die omvang daarvan

'n te wye gordel sou wees vir die son.

In daardie lig word 'n mens sodanig

dat dit onmoontlik is dat hy ooit

na'n ander gesig sal wegdraai

Want die goeie, die voorwerp van ons wil,

is geheel daarin vergaar, en daarbuite

is alles onvolmaak wat daarbinne perfek is.

(Alighieri 2002:405; Du Toit se vertaling)

Vir Dante is die kern van Beatrijs se invloed op hom, volgens Reynolds en Sayers:

...the power of her beauty to uplift him and of her knowledge and understanding to enlighten him. (Alighieri 1977:50)

Cloete (2013:55) beskryf in Die ander een is ek'n soortgelyke proses van sublimering van die Liefde wat tyd- en aardse wetmatigheid transendeer. Hy verwys na 'daardie chemie' wat 'liefdevol en hoogs aktief nog aanhou werk, al is Anna jare lank al nie meer daar nie' Hy voeg daaraan toe:
In my hartseerste oomblikke na Anna se dood was my liefde vir haar hiperaktief.

Dit is aanduiding daarvan die 'Liefde' met die hoofletter onvoltooi bly, selfs na die dood van die geliefde. (Cloete 2013:55)

Hy tipeer dit as "n wonder dat die liggaam chemiese stowwe afskei wat ons Liefde noem en wat ons soos Dante in die Goddelike komedie met 'n hoofletter skryf' (Cloete 2013:56).

Hy kom tot die gevolgtrekking dat 'die liefde waarskynlik die sterkste spirituele uitgroeisel van die liggaam is', en dat 'tussen die liefde en die gedig 'n natuurlike simbiose' bestaan (Cloete 2013:55). Ook die gedig ontglip die 'laboratorium', soos die 'Imago-liefde' wat ons begrip pypkan. Die vraag is 'wie meet die chemie, en hoe, van die gedig wat soms oor jare ontstaan, stuksgewys, of dalk in 'n oogwink in een worp, dalk in jou slaap, of in die toilet?'

Die digterlike sintuig soek, ondanks emosionele of intellektuele duisternis, of dit nou al gaan om onbegrip of emosionele pyn, na die skep van betekenis by wyse van vormgewing. Hiervan is daar menigvuldige voorbeelde in Cloete se oeuvre. Hy verwys na 'die metafoor en beeldspraak as die hartklop van die gedig' (Cloete 2013:57). In die inleiding tot Uit die wit lig van my land gesny wys die digter op die sleutelrol wat die Anna Perenna-simboliek en die Beatrijsverwysings in sy digwerk speel (Cloete 2010:opdragbladsy). Dit kan byvoorbeeld ook afgelei word uit die volgende aanhaling: 'Op baie maniere is die vrou ' $n$ wiel of haarveer in 'n digter se lewe ...' (Cloete 2013:247).

Dit herinner sterk aan Dante se Goddelike komedie met sy geometriese kosmiese skep van patrone wat volhardend reik na singewing te midde van disintegrasie. Dit is dus nie verrassend dat juis die gedig 'roetes op soek na jou' (Cloete 2010:101) begin met die volgende aanhaling van Dante wat lui: 'Dante bleef één dag in de hel, vier dagen in het vagevuur en één dag in de hemel ...' (kyk Alighieri 1947:X11).

Hiernaas word die tydsoorskryding deur 'Goddelike Lig' soos deur Augustinus verwoord, soos volg aangehaal aan die begin van die gedig 'elegiese reis': 'Maar die sewende dag is sonder aand en het geen ondergang nie, want $U$ het hom geheilig om altyddurend te bly' (Cloete 2010:101).

Die vereenselwiging met 'n Danteaanse ervaring spreek verder uit die volgende strofe:

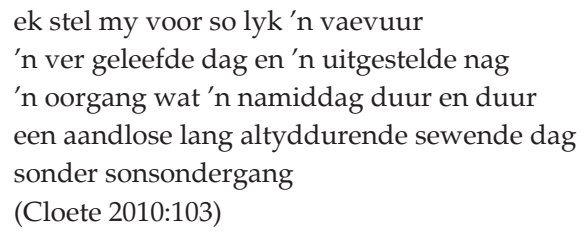

Dit is telkens die wonder dat die belewenis van die gestorwe Geliefde weer kiem tot selftransendering deur middel van en in die gedig, soos dit blyk uit die volgende strofe: 'kan julle hoor hy praat onsamehangend / byna digterlik onsamehangend / in die droomsintaksis' (Cloete 2010:110). 


\section{Die hologram as digterlike 'werklikheid'}

Daar is aan die begin verwys na die spinnerak-karakter van Cloete se oeuvre. In hierdie ondersoek het dit telkens na vore gekom. In Die ander een is ek (Cloete 2013:76) verwys hy byvoorbeeld na Charles Baudelaire se 'correspondences' 'wat ' $n$ ander manier van sien is hoe daar in elke ding fyn essense van ander dinge skuil en hoe die werklikheid 'n hologram is'. Hy vergelyk dit dan met Henry James ([1884] 1962:34) se uitspraak: 'In each of the parts there is something of all the other parts'.

Hieruit maak hy die gevolgtrekking: 'As al die bestaande dinge uit een bron ontstaan het' en "n hologram' is, is 'gedaantewisseling vanselfsprekend' en is dit 'logies dat daar in elke ding essense van ander dinge skuil'. Die digter beklemtoon: 'Let wel, hulle is verskuil en hulle is fyn! ... Die gedig het 'n oerfunksie, dit kan tot by die begin teruggaan, met één sprong van die verbeelding ...' (Cloete 2013:78).

Hierdie digterlike sienings vind weerklank in die volgende wetenskaplike waarneming van Hawking \& Mlodinow (2010):

\begin{abstract}
If a theory called the holographic principle proves correct, we and our four-dimensional world may be shadows on the boundary of a larger, five-dimensional space-time. In that case, our status in the universe is analogous to that of the goldfish. (p. 44)
\end{abstract}

Verrassend resoneer Cloete (2013:79) se uitgangspunt hierin wanneer hy skryf: 'Dit is nie 'n nuwerwetse opvatting dat alles met alles saamhang en die een ding in die ander kan oorgaan nie, dit is 'n ou insig'. Hy haal soos volg aan: 'Since ancient Greek times, philosophers have speculated that the apparent diversity of appearances conceals an underlying unity'. (Wikipedia 'Theory of everything'.) Dit gaan hier, volgens Cloete, om wat die digters van toeka al na verwys het as soortgelyk aan wat die natuurwetenskaplikes vandag ' $n$ hologram noem'.

'n Hologram word taalkundig omskryf as die patroon op 'n fotosensitiewe medium wat deur holografie vertoon en fotografies ontwikkel word. Dit kan ook verwys na 'n dokument wat geskep is deur die persoon wie se handtekening dit dra en van wie dit dan die 'spore' vertoon. Ilson (1984:806) beskryf dan die ontstaan van die hologram soos volg: 'After exposure the photographic plate draws information on the recorded object as a hologram - a pattern of light and dark areas'.

Die gedig kan by uitnemendheid geïdentifiseer word as 'n hologram, soos desgelyks die oeuvre van die digter, T.T. Cloete, wat dié insig geformuleer het. Vandaar my aanvanklike tipering van 'digterlike transparante'.

Ook in dié verband is daar deurlopende naspeurbare spore. Cloete (1998:70-71) se twee 'Paser'-gedigte waar die gedig gesien word as ' $n$ driedimensionele refleksie van 'n denkproses en wat vra om 'in perspektief' en vanuit meerdimensionele hoek waargeneem te word, is een van die relevante voorbeelde. Dit is van die talle gedigte wat wetenskaplike terminologie kreatief ver-dig. In die bundel Idiolek met een van die afdelings onder die opskrif: 'toepassings van Dante' dra die laaste afdeling van die bundel die opskrif 'holografie' met as eerste gedig daarin 'palingenese' wat verwys na 'n 'geestelike wedergeboorte' (kyk Cloete 1986:51-53). 'n Mens sou dit kon 'vertaal' as nuwe maniere van sien, alternatiewelik insig (Botha 2005:37).

Cloete se ver-beelding van kosmiese patrone sluit kreatief aan by Dante se uitleg van sy Goddelike komedie. In dié verband is die motto uit Goddelike komedie betekenisvol wat die reeks gedigte inlui na Anna se dood, naamlik dat dit 'Die liefde (is) wat die son beweeg en die sterre'. Uiteenlopende kunstenaars, waaronder die genoemde Wim Botha, het al uitdrukking gegee aan hulle interaksie met en verstaan van verwondering in Cloete se digkuns. Hieronder tel verskillende toonsettings van gedigte, asook gepaardgaande visuele opvoerings. 'n Vertolking deur 'n visuele kunstenaar van Cloete se digterlike 'hologram' bied 'n uitdaging, soos dit telkens aan elke interpreteerder bied.

Cloete (2011) se visie op 'n uiteindelik verbeeldingryke kosmies digterlike 'hologram' kan afgelei word uit die volgende versreëls uit die gedig 'fragmente van die onvolledige gedig':
die volledige gedig
kan nooit geskryf word nie
$\cdots$
al die gedigte wat gesê is in al die tale
dié wat reeds uitgesterf het
en dié van vandag en dié wat kom
is almal in hulle somtotaal te gering
om die groot register van die verhaal
van belewe te vertaal
$\cdots$
aan die maak van baie gedigte
om die steeds uitdyende onvoltooidheid
van die steeds groeiende onversadigde Gedig
in te haal kom daar geen einde nie (bl. 159)

Dit roep my aanvanklike verwysing na J. Derrida (2001) se publikasie, 'A taste for the secret' op. 'n Gevolgtrekking waartoe dit vir Derrida (1995:80) lei, is: 'To share a secret is not to know or to reveal the secret...' dit is 'the incessant repetition of the absolute beginning'.

Dit gaan in die Cloete-oeuvre om die meevoerende bewondering van 'n skepping waarin begin en einde, oorsaak en gevolg, voortdurend vervloei om nuwe perspektiewe te bied. In die gees hiervan is ook die aanhaling van Gustav Flaubert betekenisvol, wat Cloete (2011:137) gee aan die begin van die gedig '-kunde' in die Dante-afdeling van sy bundel onversadig. Dit lui: 'Do not read like the ambitious for the purpose of instruction'. Cloete voeg tussen hakies hierby: 'Met verskoning aan julle wat uit pure liefde lees'.

Cloete gee deurgaans in sy oeuvre uitdrukking aan die liefde as die sensitiefste en omvattendste medium waardeur die skeppingswonders sinvol ontdek en belééf kan word, maar desondanks misterie bly. 


\section{Persiese embleme as oerpatrone}

Aan die einde van sy weefsel 'in wit lig' herinner Cloete (2013:339) hom daaraan: 'Ek het van kleins af gewonder hoe kry mense dit reg om die patrone in 'n Persiese tapyt in te weef'. In die lig hiervan is dit insiggewend om te verneem dat 'village and nomadic rugs' oor die algemeen gebruik maak van tradisionele en oorgeërfde ontwerpe of patrone wat gewoonlik uit die geheue geweef word. Dit is meestal patrone met totemiese of simboliese assosiasies. In die meeste gevalle is dit dus afgeleide ('mutated') patrone waarvan die oorspronklike betekenis lankal vergeet is. (Bennett 1981:12). Ook dít sluit aan by Cloete se waarneming van oerpatrone wat as't ware ingeweef is in die geheue van die skepping se vele vorme en by uitnemendheid te voorskyn tree in die geheue van die kunstenaardigter.

Cloete (2013) se digtersperspektief van die woordmat is visueel kunstig vasgelê in die stofomslag van die publikasie Die ander een is ek. Die patrone van 'n Persiese mat verskyn op die wit stofomslag van die bundel, teenoor 'n enkele blok uit die geheel op die donkerrooi hardeband van die publikasie (sien stofomslag van Die ander een is ek, asook donkerrooi hardeband van Die ander een is ek).

Op soortgelyke wyse is die leitmotief van Cloete (2010) se oeuvre - Anna se profiel, simbolies verbeeld in 'n klassieke raam op die stofomslag van Uit die wit lig van my land gesny en aangrypend word dieselfde raam in slegs wit lig op 'n skoon agterblad van die bundel afgedruk, sonder die geliefde profiel. Daarmee word slegs 'wit Lig' in die raam verbeeld. (Vergelyk stofomslagfoto van Anna in raam van Uit die wit lig van my land gesny, asook die laaste wit bladsy met leë raam in Uit die wit lig van my land gesny).

Die oeuvre van Cloete (2013:58) kan oorskouend getipeer word, volgens sy eie formulering, as 'digterlike transendering wat tot vermenigvuldigde lewe ontroer'. Anna Perenna, draer en bewaarder van die lewenskiem, ontplooi daarnaas as die haarveer deur wie digterlike kreatiwiteit gestimuleer word. Daarmee sluit die twee gedigte, 'Eurinome' en 'Dali' met sy horlosiesimboliek, op verrassende wyse by mekaar aan as sleutelsimbole tot ontginning van Cloete se genoemde credo. Soos sy vrou, Anna, die dikwels gebroke digter op vele maniere lewe gestimuleer het, so speel sy 'n sleutelrol in die leweskeppende moontlikhede van (sy) andersins verloopte maar, danksy haar, vrugbare tyd.

Alles in ag genome, kan ek nie anders as om af te sluit met die geboortegedig van die digter op die drumpel van negentig jaar wat, met die opskrif 'die begeerlike mens', soos volg lui:

om my herinneringe op te teken sat

van foute het my bitter lank gevat

in fiaskowoorde wat swig

onder hulle besoedelde gewig

met gevou en gepas het ek gesoek

in 'n verskietende lang moeisame verlede

waar ek inpas en langsaam het ek tuisgekom

in die deursigtige opvoutent van my ouderdom 'n fragiele begeerlike plek wat ruik na vrede en na vars nageboorte en moederkoek (Cloete 2011:191)

In die gees hiervan is dit sinvol om aandag te gee aan die Estoniese komponis Arvo Pärt se komposisie 'Alina'. Pärt (1999) skryf na aanleiding van dié musiek:

I could compare my music to white light which contains all colours. Only a prism can divide the colours and make them appear; this prism could be the spirit of the listener.

Dié verkenning is 'n viering van 'Anna' se gedig, T.T. Cloete.

\section{Erkenning Mededingende belange}

Die outeur verklaar hiermee dat sy geen finansiële of persoonlike verbintenis het met enige party wat haar nadelig of voordelig kon beïnvloed het in die skryf van hierdie artikel nie.

\section{Literatuurverwysings}

Adkinson, R. (ed.), 1997, Sacred sex, Thames \& Hudson Ltd., London.

Alighieri, D., 1882, Dante the divine comedy with 136 illustrations, transl. F. Cary, illust. D., Gustave, Omega Books, London.

Alighieri, D., 1947, De Goddelijke komedie [Goddelike komedie], transl. P.B. Haghebaert, De Nederlandsche Boekhandel, Antwerpen.

Alighieri, D., 1977, The comedy of Dante Alighieri: Cantica 111, Paradise, transl. B. ReynoldsD. \& Sayers, Penguin Books, New York.

Alighieri, D., 2002, Die paradys, vert. D. Du Toit, Zebra Publikasies, Houtbaai.

Alighieri, D., 2010, The new life, transl. D.G. Rossetti, Cheylesmore Oresse, Goventry. Anderson, W., 1980, Dante the maker, Routledge \& Kegan Paul, London.

Aucamp, H., 1981, Volmink, Tafelberg Uitgewers, Kaapstad.

Bennett, I. (ed.), 1981, Rugs \& Carpets of the world, 2nd edn., Quarto, London.

Botha, W.F. (hoofred.), 2005, Woordeboek van die Afrikaanse taal, deel 12, Paarl Print, Paarl.

Chetwynd, T., 1993a, s.v. 'cycle of time', in Dictionary of symbols, , 2nd edn., Aquarian Press, London, vol. 2, p. 13.

Chetwynd, T., 1993b, s.v. 'maagd/virgo', in Dictionary of sacred myth, 2nd edn., Aquarian Press, London, vol. 3, p. 10.

Cirlot, J.E., 1982, s.v. 'lig', in A dictionary of symbols, 2nd edn., Vail-Ballou Press, New York, p. 17.

Cloete, T.T., 1970, Kaneel - Studies oor die poësie, prosa en die kunsteorie, Nasionale Boekhandel, Kaapstad.

Cloete, T.T., 1980, Angelliera, Tafelberg, Kaapstad.

Cloete, T.T., 1984, 'Die dromende denke van die digter', SAVAL Kongresreferate 1V.

Cloete, T.T., 1985, Allotroop, Tafelberg, Kaapstad.

Cloete, T.T. 1986, Idiolek Tafelberg, Kaapstad.

Cloete, T.T., 1989, Driepas, Tafelberg, Kaapstad.

Cloete, T.T., 1992, Met die aarde praat, Tafelberg, Kaapstad.

Cloete, T.T., 1998, Uit die hoek van my oog, Tafelberg, Kaapstad.

Cloete, T.T. 2007, Heilige nuuskierigheid Tafelberg, Kaapstad.

Cloete, T.T., 2010, Uit die wit lig van my land gesny, Pooka, Plettenbergbaai.

Cloete, T.T., 2011, Onversadig, Tafelberg, Kaapstad.

Cloete, T.T., 2013, Die ander een is ek, Pooka, Plettenbergbaai.

Colin, D., 2000, s.v. 'virgo', Dictionary of symbols, myths \& legends, Octopus Publishing Group, London, p. 7.

Derrida, J., 1995, The gift of death, 2nd edn., transl. D. Wills, University of Chicago Press, Chicago, IL.

Derrida, J. \& Ferraris, M., 2001, A taste for the secret, 2nd edn., transl. Giacomo Donis, Polity Press, Cambridge.

De Villiers, M., Smuts, J., Eksteen, L.C., Gouws, R.H., 1985, Nasionale woordeboek Afrikaanse woordverklaring, 2de uitgawe, Nasionale Opvoedkundige Uitgewery, Kaapstad.

De Vries, A., 1974, s.v. 'vlinder', in Dictionary of symbols \& imagery, North Holland Publishing, Amsterdam, p. 13. 
Evans, B., 1970, s.v. 'myths', in Dictionary of mythology, Dell Publishing, New York, p. 6. Fontana, D., 2010, The new secret language of symbols, Duncan Baird, London.

Geggus, R., 1961, Die wit in die poësie, Uitgeverij Heijnis N.V., Amsterdam.

Hawking, S. \& Mlodinow, L., 2010, The grand design, Bantam Press, London.

Ilson, R., 1984, Reader's Digest great illustrated dictionary, Reader's Digest Association, London.

James, H., [1884] 1962, 'The art of fiction', in L. Edel (ed.), The house of fiction, p. 34, Mercury Books, London.

Kristeva, J., 1993, Proust and the sense of time, Columbia University Press, Columbia. NY.

Kroeze, J.H., 1967, Die tuin van Eden, N.G. Kerk-Boekhandel, Pretoria.

Kruyskamp, C. 1961, s.v. 'saffierlig', in Groot woordenboek der Nederlandse Taal Martinus Nijhoff, 's-Gravenhage, bl. 10.

Kuypers, K., 1966, s.v. 'simbool', Elseviers filosofische en psychologische encyclopedie, Elsevier, Amsterdam, p. 6 .

Laurie, T., 1997, Skietspoel, Tafelberg, Kaapstad.
Matthews, B. (ed.), 1993, s.v. 'son', in The Herder dictionary of symbols, Chiron Publications, Willmette, p. 11.

Pärt, A., 1999, Alina, ECM Records GmbH, Munich.

Rothenstein, J., (ed.), 1972, s.v. 'The persistence of memory', in The new international illustrated encyclopedia of art, Greystone Press, New York, vol. 6, p. 12.

Stern, S., 1989, Proust Swann's way, Cambridge University Press, Cambridge.

Topstones (Pty) Ltd., 1996, The magic of gemstones, Topstones (Pty) Ltd., Simon's Town.

Toynbee, P., 1978, s.v. 'Beatrice', in A dictionary of proper names and notable matters in the works of Dante, Clarendon Press, Oxford, p. 16

Tresidder, J. (ed.), 2004, s.v. 'saffier', in The complete dictionary of symbols in myth, art and literature, Duncan Baird, London, p. 10.

Weyers, F., 2005, Salvador Dalí, Könemann, Cambridge.

Wilson, A.N., 2011, Dante in love, Atlantic Books, London.

Zellini, P., 2004, A brief history of infinity, 2nd edn., Allen Lane, London. 